\title{
Life Cycle Cost Structure of a Government Office Green Building - Case of the Ministry of Public Works and Housing Main Building
}

\author{
Domenico Adi Nugroho $^{1, a)}$, Hitapriya Suprayitno ${ }^{1, b)}$ \& Tri Joko Wahyu Adi ${ }^{1, c)}$ \\ ${ }^{1)}$ Civil Engineering Department, Institut Teknologi Sepuluh Nopember (ITS), Surabaya, Indonesia. \\ Correspondents : ${ }^{a)}$ domenico.nugroho@gmail.com, ${ }^{b)}$ suprayitno.hita@ gmail.com \& \\ ${ }^{c)}$ tri_joko@ce.its.ac.id
}

\begin{abstract}
One of the efforts to reduce the large impact of building sectors on the environment is the concept of environmentally friendly building known as green buildings. With the increasing global interest in this concept, green building development in Indonesia was also expected to increase. Cost is one of the most important focus for promoting green buildings, so it is necessary to conduct a cost analysis of a green building to provide a clearer understanding of the life cycle cost structure of a green building in its life cycle as a study to develop the knowledge of Infrastructure Asset Management. In this study data related to the cost component of the government office green building was identified to determine the overall cost of the building from the beginning of its construction until recent year, which can be described as: Initial Cost, Operation and Maintenance Cost, and Energy Cost. The result of this study finds out that during 8 year period of its lifetime the total building expenditure is $\mathrm{Rp} 483.649 .711 .849,00$ and the life cycle cost structure percentage are: initial cost 43,94\%, operation and maintenance cost $39,48 \%$, and energy cost $16,57 \%$. The total energy cost saving is Rp 28.072.536.738,00.
\end{abstract}

Keywords : infrastructure asset management, life cycle cost structure, green building, government office.

\section{INTRODUCTION}

Nowadays the awareness about climate change and the environment has increased significantly and aroused great attention from governments around the world. Various movements were carried out to protect the earth by implementing efforts to use energy efficiently and minimizing the environmental impact. The building sector is one of the major targets for improvement as according to UNEP (2009) this sector has estimated to have consumed nearly $40 \%$ of world's energy consumption, $30 \%$ raw material use, $25 \%$ solid waste product, $25 \%$ water use, $12 \%$ of land use, and $33 \%$ of related global greenhouse gas (GHG) emissions. Many attempts have been initiated to evaluate the environmental impacts of building, their materials, components, systems, and to explore any opportunities to reduce their environmental impacts (Chau et al., 2015). Any efforts to reduce carbon emissions and saving energy in the building sector will greatly influence the efforts to reduce global warming in general.

Since 2011 the Government of Indonesia has committed to voluntarily reduce GHG emissions by $26 \%$ until 2020 under business as usual scenario and can reach up to $41 \%$ with international support (Bappenas, 2012). The follow up to the government commitments is the issuance of Minister of Public Works Regulation No. 11 of 2012 concerning the National Action Plan for Mitigation and Adaptation to Climate Change 2012-2020 and Minister of Public 
Works and Housing Regulation No. 02/PRT/M/2015 on Green Buildings to reduce greenhouse gas (GHG) emissions originated from buildings.

Green building is the practice of creating structures and using processes that are environmentally responsible and resource-efficient throughout a building's life-cycle from siting to design, construction, operation, maintenance, renovation, and deconstruction. This practice expands and complements the classical building design concerns of economy, utility, durability, and comfort. Green building is also known as a sustainable or high-performance building (U.S. EPA, 2016). The assessment of a building to be declared as a Green Building is conducted by appraisal institutions that are incorporated in the World Green Building Council (WorldGBC) based in Toronto, Canada. There are several leading appraisal institutions for green building assessment such as Leadership in Energy and Environmental Design (LEED, United States), BRE Environmental Assessment Method (BREEAM, United Kingdom), Green Building Council of Australia Green Star (GBCA, Australia) and Green Mark Scheme (Singapore) (Zuo \& Zao, 2014). Each of these appraisal institutions has its rating system and criteria for assessment that are slightly different from each other but the purpose of the assessment is the same which is assessing the level of fulfillment of sustainable building requirements (Firsani \& Utomo, 2012). As for Indonesia the appraisal institution for green building is Green Building Council Indonesia (GBCI). GBCI was founded in 2009 by professionals in the building design and construction sector who have a great concern for the application of the concept of green buildings and aims to apply the principles of green buildings in the building industry sector in Indonesia. The rating system used by GBCI to certify Green Buildings are based on modified standards that unique to the Indonesian climate and condition and the assessment tool called GREENSHIP rating (GBCI, 2019).

Based on the list in GBCI currently there are 20 buildings in Indonesia registered as green buildings and have GREENSHIP certification. One of the government office building included in this list are the Ministry of Public Works and Housing Main Building. The Ministry of Public Works and Housing Main Building is situated inside the Central Office Complex of the Ministry of Public Works and Housing which are located on Jalan Pattimura 20 Kebayoran Baru, South Jakarta, an office area with an area of $54000 \mathrm{~m}^{2}$ and occupied by more than 5000 employees. The Ministry of Public Works and Housing Main Building has been awarded the Greenship Platinum certification from the Green Building Council Indonesia, the highest rating in its assessment tool.

With the increasing global interest in the concept of sustainability, green building development in Indonesia was also expected to increase. Since cost is one of the most crucial concerns in promoting green buildings there is a need to provide robust evidence to counter the high initial cost barrier. The foregoing review indicates that cost commitments of green buildings is the prime concern and of contradictory views to the different context, type of building, weather condition, site conditions, etc. (Weerasinghe et al., 2017). Public Infrastructure financial characteristics mainly concern with the infrastructure cost and revenue, along its life cycle. The cost always exists with or without any revenue. Infrastructure Life Cycle Cost is in correlation with the Infrastructure Life Cycle phenomenon (PP 27/2014); Soemitro \& Suprayitno, 2020). In relation with the management of infrastructure and facility assets, by Basic Principle, Infrastructure Asset Management is a program, knowledge and science to manage the infrastructure, through the whole of its life cycle, for the infrastructure to be able to sustainably function effectively and efficiently in accordance to sustainable principles (economic, social, \& environmental) (Suprayitno \& Soemitro, 2019). The task of Infrastructure Asset Management to evaluate the quality of green aspects of buildings is very important. Therefore it is necessary to conduct a life cycle cost analysis of the Green Building to provide a clearer understanding of the overall cost and the life cycle cost structure of a green building and thus enable the government and interested parties to be able to make decisions 
based on this information in the construction of office buildings in the future and as a study to develop the knowledge of Infrastructure Asset Management.

\section{LITERATURE REVIEW}

\section{Green Building}

Green building is a new building or an existing building that has been planned, implemented and operated by taking into consideration the environmental/ecosystems factors and meets certain requirements of sustainability such as: land use, indoor air quality, water usage saving, energy saving, materials saving, and reduce waste (GBCI, 2019).

Based on the Minister of Public Works and Public Housing Regulation Green Buildings are buildings that meet the building requirements and have significant measurable performance in energy saving, water usage saving, and other resources through the application of the principles of green buildings following its functions and classifications in each stage of the development (Permen PU 02/PRT/M/2015).

\section{Life Cycle Cost}

Basic Components of Public Infrastructure Life Cycle Costs consists of investment cost, administration cost, annual operation cost, annual maintenance cost, rehabilitation cost, development cost, removal cost, and annual management cost. It must be noted that the Investment Cost and the Development Cost are normally far higher than the Annual Operation, and Annual Maintenance Cost. The Rehabilitation Cost can also be very high, it depends on the seriousness of infrastructure damage (Soemitro \& Suprayitno, 2020).

Life cycle costs are summations of cost estimates from inception to disposal for both equipment and projects as determined by an analytical study and estimate of total costs experienced during their life. The objective of LCC analysis is to choose the most costs effective approach from a series of alternatives so the least long term cost of ownership is achieved (Barringer, 2003). According to Kelly and Male (1993) the definition of life-cycle costing is a technique for economic evaluation which accounts for all relevant costs during the investor's time horizon and adjusting for the time value of money. The cost of the life cycle of an item is the sum of all expenses relating to the item since designed to unused (Pujawan, 2004). Based on these definitions LCC can be formulated as follows:

$$
\text { LCC }=\text { Initial Cost }+ \text { Cost of Usage }+ \text { Cost of Care and Replacement. }
$$

wherein the initial cost is the cost of the planning and execution of the building, the cost of usage is the cost incurred during the building operations, cost of care and replacement are costs for maintenance and replacement the constituent components of the building during the design life of the building (Kaming, 2017).

\section{RESEARCH METHODS}

The general objective is to identify cost components of Green Building projects in government offices from the design stage to the specified age and determine the life cycle cost structure by using a real case The Ministry of Public Works and Housing Main Building. For the first step, data collection methods used in this study includes the preparation stage to formulate the research problem, research objectives, and explore data to the stakeholders involved in the project. The next stage is data collection by taking the field survey of the research location and conduct the permitting process for data collection to the stakeholders which are Bureau of General Affairs Ministry of Public Works and Housing as the owner, SNVT P4SBPUPRL as Construction Project Officer and PT. Airkon Pratama as building management operator. Later Data Analysis was performed after the data was collected to create 
a life cycle cost calculation using MSExcel, followed by discussion and conclusion to this research.

\section{Building under Study}

The Ministry of Public Works and Housing Main Building is situated on Jalan Pattimura 20 Kebayoran Baru, South Jakarta as one of the office building inside the Central Office Complex of the Ministry of Public Works and Housing, an office area with an area of 53.846 $\mathrm{m}^{2}$ which were designed to be a green site or green campus.

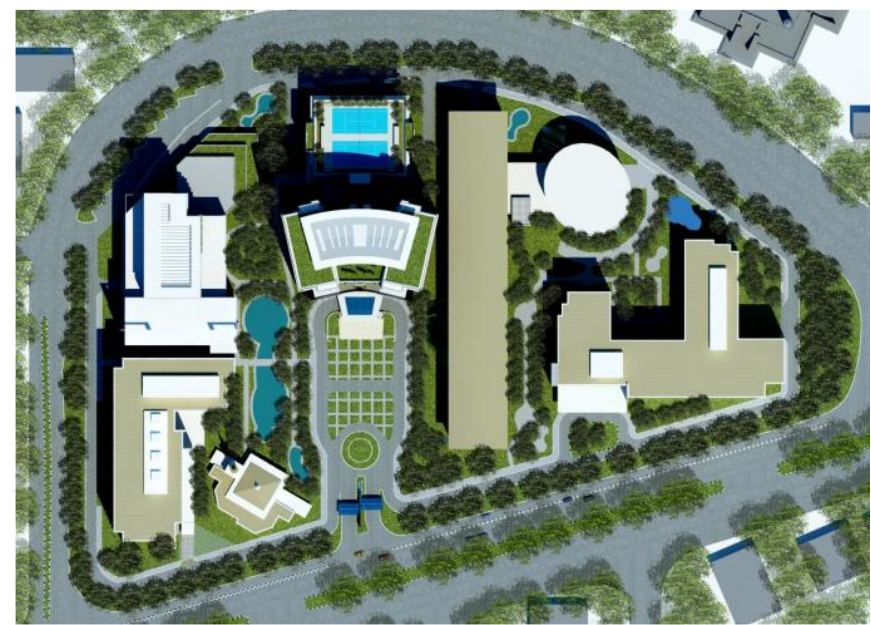

Figure 1. Green Campus Ministry of Public Works and Housing

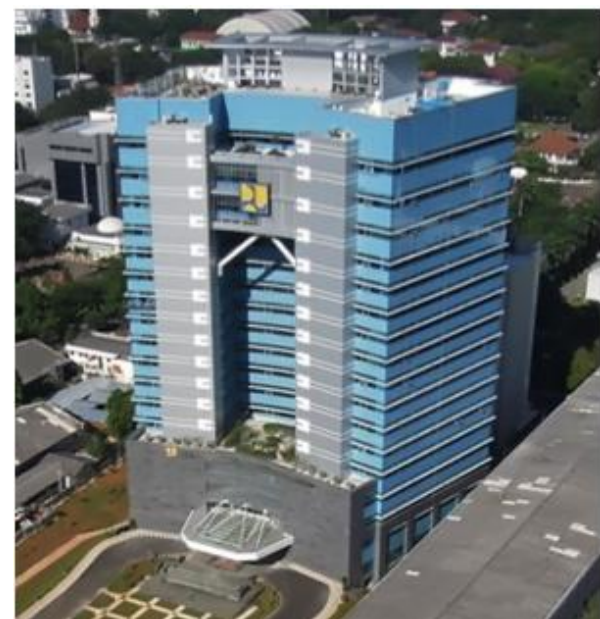

Figure 2. Ministry of Public Work and Housing Main Building

This building is the first ministerial office building that applied the green building concept. Based on the vision to make the Ministry of Public Works and Housing become an avantgarde in building technology applications, the development of this building aims to make an example for other governmental projects. The details administration of the project are:

Owner

Construction Project Officer

Construction Management Consultant

Design Consultant

Contractor

Type of Contract

Construction Start Date

Working Period

$\mathrm{PHO} / \mathrm{FHO}$

Total site area

Total softscape area

Total number of floors

Gross Floor Area

Net Floor Area

Total number car park floors

Car park area

Number of occupant

Building Management Operator
: Bureau of General Affairs, Secretariat General, Ministry of Public Works and Housing

: SNVT-(P4SBPUL), Secretariat General, Ministry of Public Works and Housing

PT. Artefak Arkindo

PT. Jakarta Konsultindo

KSO PP-Brantas

Multi Years Contract (Lump Sum)

$8^{\text {th }}$ December 2010

391 days

$30^{\text {th }}$ December $2011 / 28^{\text {th }}$ June 2012

: $15.440 \mathrm{~m}^{2}$

: $6.656 \mathrm{~m}^{2}$

- 17 floors, 1 basement

: $25.590 \mathrm{~m}^{2}$

: $21.193 \mathrm{~m}^{2}$

: 12 floors

: $20.381 \mathrm{~m}^{2}$

: 1.545 person

: PT. Airkon Pratama 
Ministry of Public Works and Housing Main Building was granted the Platinum level of New Building Greenship Certification from Green Building Council Indonesia (GBCI) in 2013 and renewed in 2016. GREENSHIP were green building rating tools based on a unique Indonesian environment and organized by GBCI (Erizal et al., 2019). Points achieved were 75 (74.26\%) from a maximum of 101 points available.

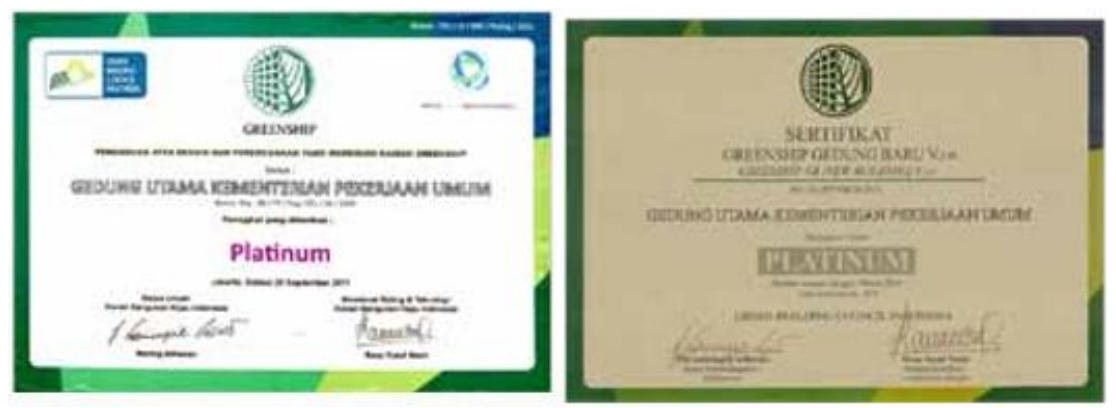

Figure 3. Greenship Certificates for Design Planning and New Building Final Assessment

Green Building aspect that was incorporated in the Ministry of Public Works and Housing Main Building are as follows :

\section{Energy Efficiency - Active and Passive Design}

a. Orientation and Building Design

Design modification applied to anticipate excessive sun radiation with minimizing area of west and east zone while maximizing area of north and south zone, change the rectangular form into " $\mathrm{H}$ " form, set up office room at north and south of the building, and create public and service area at the middle of the building. Design modification is a narrow building form to maximizing daylight performance. Other than that by placing the Parking Building on the west side/zone of the building to reduce sun exposure, those parking zones still get optimal natural daylight.
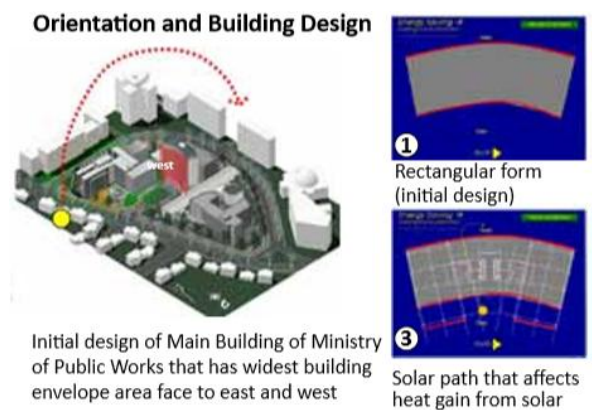

Solar path that affects Design modification heat gain
radiation

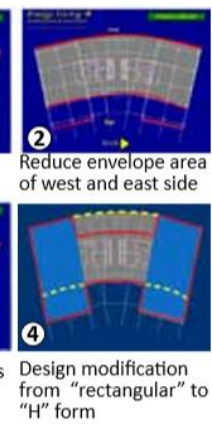
" $\mathrm{H}$ " form

Figure 4. Orientation and Building design

b. Facade Design

Some strategies conducted to handle solar radiation from windows to decrease Overall Thermal Transfer Value (OTTV) which are :

- Use thermal resistant glass for windows to support the energy efficiency program, which are: stopsol super silver dark blue $8 \mathrm{~mm}$, plate glass-cladding 0.015

- Provide insulation on the wall: external surface film, cladding aluminium, calcium silicate/gypsum, fiberglass insulation internal surface film.

- Installing the sun shading on windows.

- Installing perforated material on the west side to control solar radiation and increase natural lighting. 


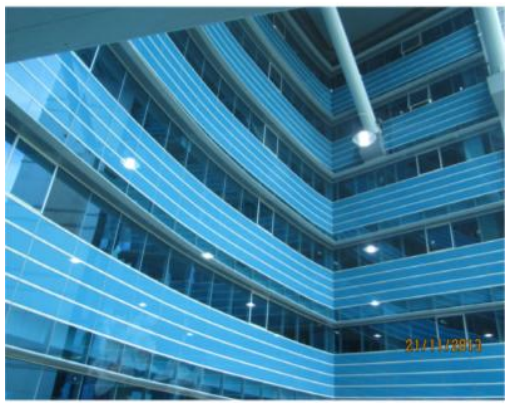

Figure 6. Façade

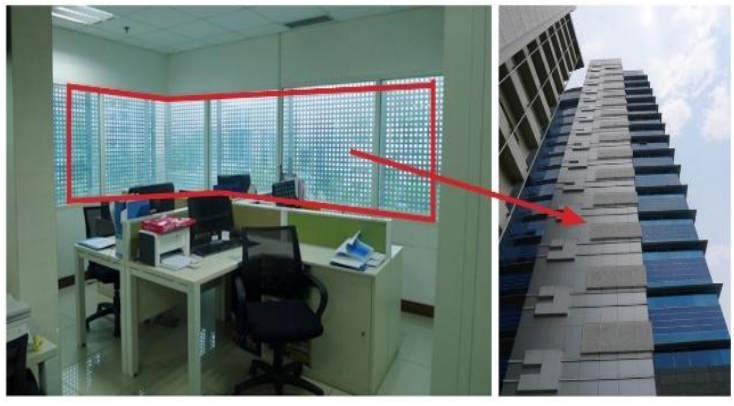

Figure 7. Perforated Metal placement

c. Daylighting: to optimize utilization of daylighting on this building some strategies have been done :

- Installing the sun shading on windows to adjust and divert direct sunlight, so that natural lighting can enter optimally by making it reflected to ceiling and redistributed to the floor to expand the daylighting area.

- By applying strategy above, artificial lighting can be reduced at noon because lamps on the outer zone (near to window) can be turned off by that time.

- Sun shading installation resulted in a $47 \%$ room area illuminated by sunlight with an illumination value of 300 lux.

- Office room design with clear glass partition with many openings, so that natural lighting can be distributed to the deepest area of the room.

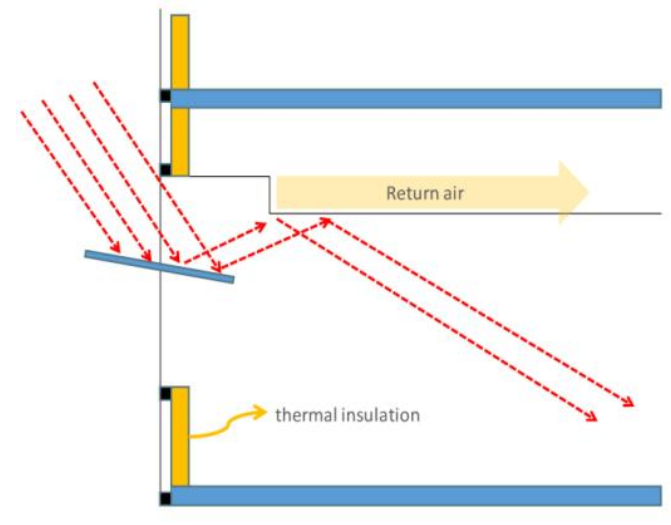

Figure 8. Sun shading

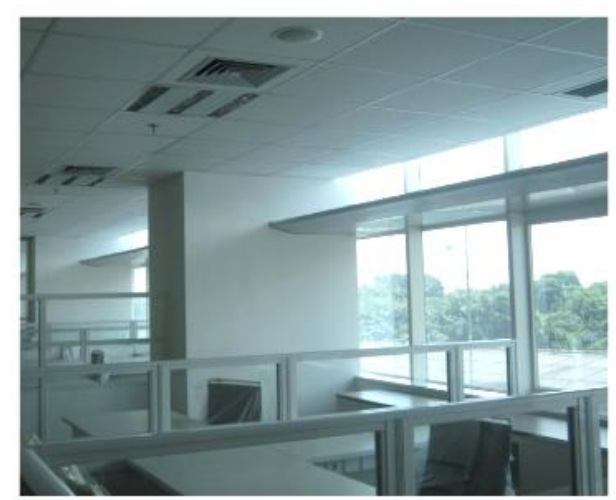

Figure 9. Indoor natural lighting

d. Zoning for integrated lighting and daylighting

The lighting system was designed by applying a zone system between natural and nonnatural lighting. Lux sensor installed to monitor the illuminance level of the room, which will turn off automatically the artificial lighting within the natural lighting area if the room illuminance reaches more than 300 lux. Therefore it reduces the energy consumption of artificial lighting. Motion sensors will turn off lamps if it detects no movement inside the room and vice versa will turn on lamps if detecting any movement inside the room. While, scheduling control the on-off of lamps at a predetermined time.

e. Natural Ventilation

Natural ventilation is located in the lobby area, a public area along the west wall. Parking building without walls on the periphery allows outdoor air distribution to substitute mechanical ventilation.

f. Other passive design concepts:

- Integrated elevator lobby and main stairs: stairs placed on edge of elevator lobby corridor to reduce lift usage. This facility expects occupants to use stairs when going to the neighboring floor (one or two floors upward or downward). 
- Expansion of softscape area from $21.93 \%$ to $33.53 \%$ and hardscape area reduce from $41.25 \%$ to $32.58 \%$.

g. Air-conditioning system

Air conditioning is designed by a centralized air conditioning system that has several energy efficiency features, that are:

- Use 3 (three) units water cooled screw chiller (2 chillers running and 1 chiller standby) with capacity for each $300 \mathrm{RT}$. The chiller is using environmental-friendly refrigerant R134.

- Chilled and condenser water pump equipped with Variable Speed Drive (VSD).

- Use 2 (two) units cross flow closed type cooling tower each of 3 (three) cells system with heat rejection capacity for each is $510 \mathrm{RT}$ and make-up water consumption is $30 \%$ less compared to open type.

- On the airside using with Fan Coil Unit (FCU) to allow for individual control.

- Motorized modulating 2-way valves installed on every FCU to control cooling capacity to overcome cooling load variety.

- Chiller system controlled by Building Automation System, the SetPoint (SP) determined appropriately with load condition per FCU. BAS can monitor temperature at rooms (Point Value, PV)) and also can monitor the opening percentage of the motorized 2-way valve for every FCU.

h. Lighting systems: the use of T5 and LED lamp with $10 \mathrm{~W} / \mathrm{m}^{2}$ energy expenditure.

i. Vertical transportation: with 6 (six) units passenger lift, 1 (one) unit executive lift, 1 (one) unit service lift, the strategy applied to achieve energy efficiency for vertical transportation is by applying Variable Voltage Variable Frequency (VVVF) feature. This feature will cause rotation of motor become softer (soft starting) and inrush current become lower. Car light/fan shut off also applied to decrease energy consumption because this feature will automatically shut off lamp and fan in lift when lift idle.

2. Renewable energy:

Installed solar PV panels (solar cells) were placed on park lamps. Solar-cell Lamp 1 (201 IDGL Venus HPLP $50 \mathrm{~W}$ park lamps, $4 \mathrm{~m}$ height, 31 pieces) and Solar-cell Lamp 2 (HPLH 500W park lamps, $9 \mathrm{~m}$ height, 8 pieces). The total capacity of renewable energy produced is $14,430 \mathrm{kWh} /$ year.

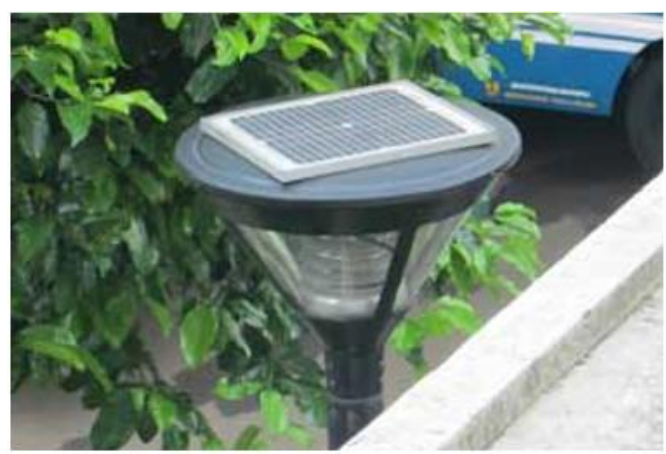

Figure 10. Mounted Solar PV Panels

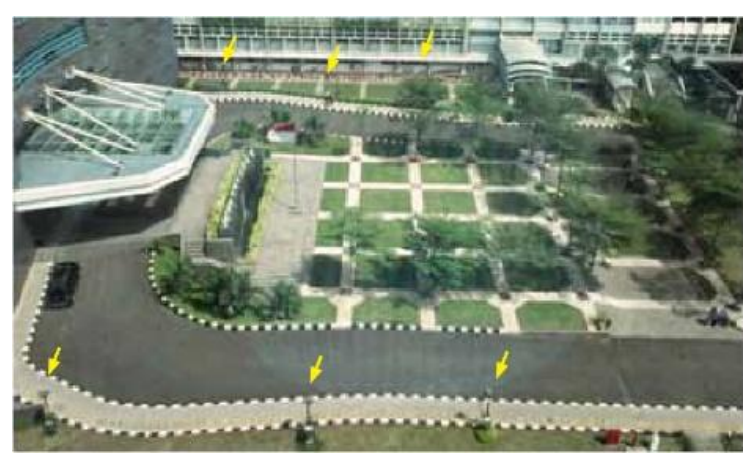

Figure 11. Solar cell garden lamps position

3. Water Efficiency

A strategy to decrease water consumption is by:

- Using water usage saving fixtures: $72 \%$ under the SNI standard, such as low flow sink taps, wall taps and showers

- Recycled water; greywater is processed in Sewage Treatment Plant (STP) and produces recycle water for water landscaping, flushing, and make up for water cooling tower. 
Black-water from jet spray, urinary, and flushing toilets will be processed before wasted to city sewer.

- Rainwater harvesting; due to eagerness to implement green concept (zero run off) in Ministry Public Works and Housing neighborhood, the ground rainwater tank installed (capacity $200 \mathrm{~m}^{3}$ in zone A and $200 \mathrm{~m}^{3}$ in zone B). After treatment, this clean water is distributed to the buildings on-site as domestic water. By this strategy, there is no water go to city sewer

- Water treatment/recycling capacity: The recycling capacity: $150 \mathrm{~m}^{3} / \mathrm{day}$, which is used for irrigation, flushing, and makeup water cooling tower.

\section{Environmental Sustainability}

a. Sustainable construction

- Use of materials/ products with recycled content: Calsiboard Parapet

- Environmentally friendly products with green label certification: using $83.42 \%$ environment friendly certified material such as ISO 14001, Refrigerant R134a for chiller, Using 100\% certified wood (FAKO - Faktur Angkut Kayu Olahan).

- Good Environmental Management system during construction: Reusing of liquid waste (dewatering method), using metal deck slab to reduce wood formwork material, Waste management on construction.

b. Materials (Percentage of Using Local Material: using local materials: $66.47 \%$, Using material within a radius of $1,000 \mathrm{~km}: 64.17 \%$

c. Greenery

- Restoration and Conservation of existing trees: replenishment of site area and trees planted will affect to improvement of on-site microclimate.

Site revitalization was conducted and resulted in the expansion of softscape area from $21.93 \%$ to $33.54 \%$

- Vertical greenery: Total wall garden area: $969 \mathrm{~m}^{2}$ located on the breezeway and hanging garden on the $2^{\text {nd }}$ floor.

- Roof gardens: Total roof garden area: $132 \mathrm{~m}^{2}$, located on roof garden $5^{\text {th }}$ floor, roof garden $17^{\text {th }}$ floor, and roof garden $18^{\text {th }}$ floor.

d. Provision of recycling facilities Storage, collection, and disposal (waste management). by implementing zero waste management.

e. Sustainable Site (external environment)

- Public transport accessibility: walking distance from the bus stop: $280 \mathrm{~m}$

- Barrier-free site and public access: apply pedestrian connectivity system that connect one building to another by providing pedestrian track and limit the movement of the vehicle inside the site.

\section{Indoor Environment}

a. Indoor thermal designed and conditioned at a temperature of $25{ }^{\circ} \mathrm{C}$ with a relative humidity of 60\% (SNI 03-6572-2001).

b. Number of Ventilation air per person (CFM/person) The flow rate of outdoor air introduction compliance with Indonesia National Standard 03-6572-2001 table 4.4.2 for office area, it is $5 \mathrm{CFM} /$ person.

c. Use of low volatile organic compound (VOC) paints and coatings.

d. Use of a high-frequency ballast to avoid a low-frequency flickering Lighting in this building uses a high-frequency ballasts.

e. Pollution control: $\mathrm{CO}_{2}$ sensor installed in Main Building of Ministry of Public Works and Housing; Greystone CO2 Detector, Non-Dispersive Infrared (NDIR) sensor. 
f. Environmental tobacco smoke (ETS) and smoke control: The smoking bans regulation has been issued and socialized to the building occupant, put up smoking signs, not providing a smoking room.

g. Lighting illumination: Based on Simulation (Dialux): 76\% (19,404 $\left.\mathrm{m}^{2}\right)$ area has more than 300 lux

h. Others: Outside view to reduce eye tiredness by giving a long-range view and providing a visual connection to the outside the building.

\section{DATA ANALYSIS}

After obtaining permission to research at the predetermined location, an in-depth interview and data collection were conducted to provide actual data related to cost with the collaboration of stakeholders for this green building project. The results are as follows:

\section{Initial Cost}

All costs of initial construction work on the building, including the building work costs, which means the cost of building works and external works (presented in the SFCA element cost structure); and other construction-related costs, which mean all costs payable by the client in connection with the building or constructed asset (Kaming, 2017). The initial cost for this project is presented in Table 1.

Table 1. Initial Cost

\begin{tabular}{|c|l|r|r|}
\hline Num. & \multicolumn{1}{|c|}{ Contract } & \multicolumn{1}{c|}{ Cost } & Percentage \\
& & $R p$ & \multicolumn{1}{c}{$\%$} \\
\hline 1 & Design \& Supervision & $4,077,293,000.00$ & $1.02 \%$ \\
\hline 2 & Construction Management & $6,516,620,000.00$ & $1.62 \%$ \\
\hline 3 & Construction & $391,022,920,582.00$ & $97.36 \%$ \\
\hline & TOTAL & $401,616,833,582.00$ & $100.00 \%$ \\
\hline
\end{tabular}

\section{Operation \& Maintenance Cost}

Operation costs are all costs of operating the building or facility arising from the building itself rather than from its occupancy. It includes: routine and specialist cleaning; windows and external surfaces such as cleaning windows, glazed screens, cladding, sun screening etc.; internal cleaning; and external works cleaning (Kaming, 2017).

Maintenance costs are all costs of replacement, maintenance, repair, and adaptation of the constructed asset (presented in the SFCA element cost structure. They consist of: major replacement costs, includes scheduled replacement and major components and this will form the detailed asset life cycle replacement program; minor replacement and repairs costs, scheduled replacement of parts and scheduled maintenance and repairs to components and associated making good and minor redecorations including planned preventative maintenance; unscheduled replacement, repairs and maintenance costs, allowance for unforeseen maintenance arising from early failure, inappropriate use, etc.; redecorations, scheduled redecorations; refurbishment and adaptation costs, scheduled refurbishment and adaptation during the period of analysis (Kaming, 2017).

Ministry of Public Works and Housing Main Building uses service from a third party contractor to operate the building and act as building management. The building owner (Bureau of General Affairs) makes a contract with PT. Airkon Pratama every year to operate and maintain the building with the principal of green. The scope of work for building management activities in the Main Building includes operational, maintenance and administrative activities. All operational, maintenance, and management activities of the Main Building and Parking 
Building must be based on the Green concept which includes aspects: energy saving, water usage saving, and environmentally friendly. Green O\&M focuses on energy and water consumption, which will be monitored and controlled to achieve a high-performance building level. To measure the level of achievement a set of Key Performance Indicator used to evaluate the performance, below are some of the benchmarks :

Table 2. Key Performance Indicator of Green O\&M

\begin{tabular}{|c|c|c|}
\hline KPI Descriptions & References & Reference \\
\hline Energy usage according to benchmark & Less than $10 \%$ & $140 \mathrm{KWh} / \mathrm{m}^{2}$.year \\
\hline $\begin{array}{l}\text { Water consumption according to } \\
\text { benchmark }\end{array}$ & Less than $10 \%$ & $\begin{array}{l}83 \% \text { in rainy season } 61 \% \\
\text { in summer }\end{array}$ \\
\hline $\begin{array}{l}20 \text { minutes responsiveness complaint } \\
\text { achievement }\end{array}$ & 5 complaints per month & WO Number / each month \\
\hline Preventive Presentation achievement & At Least $75 \%$ & $\begin{array}{l}\text { Total Preventive } \\
\text { Maintenance }\end{array}$ \\
\hline The average of energy efficiency chiller & $5 \%$ by AHRI Standard & $\begin{array}{l}\mathrm{KW} / \mathrm{TR}=0.569 \text { pada saat } \\
\text { beban penuh }\end{array}$ \\
\hline The average of pending complaints & 2 complaints per month & $\begin{array}{l}550 / 590 \mathrm{KW} / \mathrm{TR}=0569 \\
\text { (full load) }\end{array}$ \\
\hline Benchmark & & \\
\hline
\end{tabular}

Preventive and minor maintenance was carried out by building management to maintain the performance of the building, while major maintenance was carried out by the Bureau of General Affairs. Data collected regarding the contracts for operation and maintenance cost from the beginning of operation until recent year are as follow :

Table 3. Building Management Contracts

\begin{tabular}{|c|c|r|c|}
\hline Num. & Year & \multicolumn{1}{c|}{ Contract Cost } & Contract Pe riod \\
& & $R p$ & \\
\hline 1 & 2012 & $2,802,705,000.00$ & 5 months \\
\hline 2 & 2013 & $5,497,045,076.00$ & 1 year \\
\hline 3 & 2014 & $6,706,812,827.00$ & 1 year \\
\hline 4 & 2015 & $7,729,882,600.00$ & 1 year \\
\hline 5 & 2016 & $7,989,000,000.00$ & 1 year \\
\hline 6 & 2017 & $7,507,000,000.00$ & 1 year \\
\hline 7 & 2018 & $7,606,973,711.00$ & 1 year \\
\hline 8 & 2019 & $633,914,477.00$ & 4 months \\
\cline { 2 - 4 } & & $7,510,434,000.00$ & 8 months \\
\hline
\end{tabular}

The Building Management team are consisting of 106 personnel in total, which are :

1. Management: Building Manager, Head of Mechanical Electrical Plumbing \& IT Division, Head of Civil/Architecture Division, Head of Secretariat (4 personnel).

2. Mechanical, Electrical, Plumbing, and IT Division: 33 personnel.

3. Civil and Architecture Division: 65 personnel.

4. Secretariat: 4 personnel. 
Based on the Building Management Contract of 2018 (PT. Airkon Pratama) there are 4 major work category in conducting the operation and maintenance of the green building, which are :

1. Personnel Cost

a. Management Personnel

b. Technical Personnel

2. Cleaning Services

a. Cleaning Services Consumables

- MEP and IT (Audio Visual) Equipment Cleaning and Other Services

- Floor dan workspace cleaning

- Landscape and garden cleaning

b. Cleaning Services Equipment rent

- MEP and IT (Audio Visual) Equipment Cleaning and Other Services

- Landscape and garden cleaning tools

- Washroom and hygiene equipment rentals

3. Performance services

a. Retro-commissioning

b. Periodic Inspection (Lift, STP, BAS, Fire Alarm, Chiller, Genset \& Panels, Trafo)

4. Additional Services:

Processing documents permit for Lift, Genset, Gondola, Fire Alarm System dan STP.

The proportional Cost for Building Management activities are shown in the figure below :

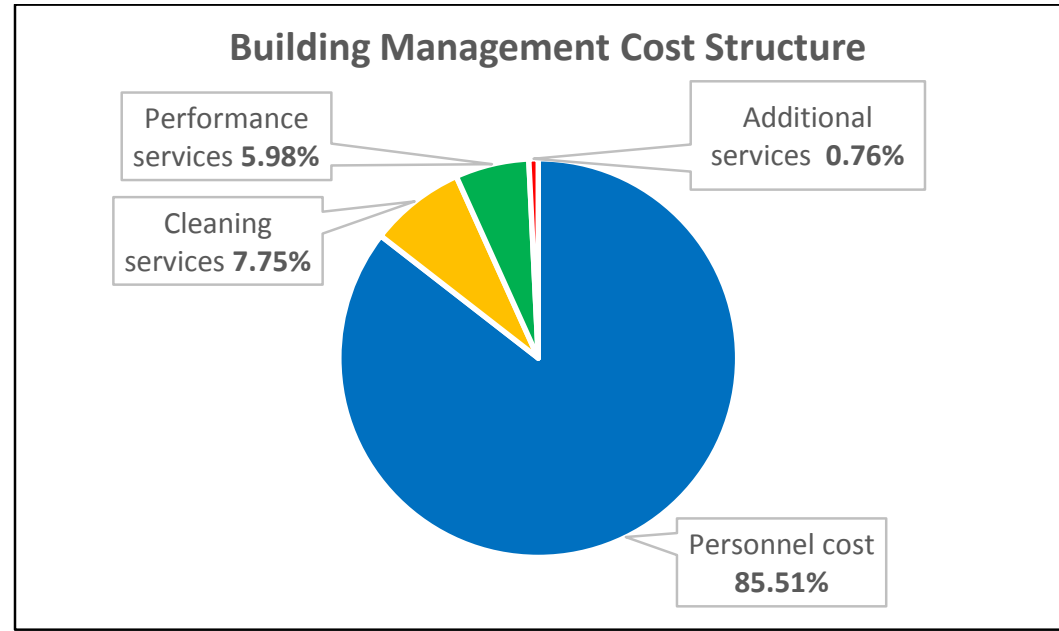

Figure 12. Building Management Cost Structure

Maintenance work was conducted by separate third party service contractors for several kinds of work including mechanical, electrical, plumbing, civil, architecture, and landscape. Most of the maintenance work was being done regarding the building improvements in civil, architecture, and supporting facilities. From the data collected there was no major maintenance being done to the building before 2017 because the building is still relatively new and preventive maintenances was being done on a regular basis by the Building Management team. Table 4 below shows the major maintenance of the building that was carried out by the Bureau of General Affairs starting from the year 2017 until recent year. 
Table 4. Maintenance Contracts

\begin{tabular}{|c|c|c|}
\hline \multirow[t]{2}{*}{ Year } & \multirow[t]{2}{*}{ Type of Work } & Contract Cost \\
\hline & & Rp/year \\
\hline \multirow[t]{7}{*}{2017} & Workspace improvements & $97,807,800.00$ \\
\hline & 1st 2nd and 3rd floor improvements & $197,061,000.00$ \\
\hline & Hall and 9th floor improvements & $150,833,000.00$ \\
\hline & Indoor building information network maintenance & $169,125,000.00$ \\
\hline & Sewage Treatment Plant maintenance & $63,415,000.00$ \\
\hline & Lift maintenance and repair & $188,815,000.00$ \\
\hline & 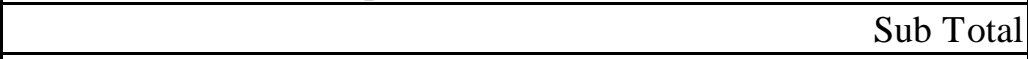 & $867,056,800.00$ \\
\hline \multirow[t]{13}{*}{2018} & $\begin{array}{l}\text { Changes in the elevator operational system by adding a BSO (Bank } \\
\text { Separate Operation) program }\end{array}$ & $116,600,000.00$ \\
\hline & Fitness room and basement hall maintenance & $190,597,000.00$ \\
\hline & Pantry and interior wall maintenance & $150,284,000.00$ \\
\hline & Rooftop improvements & $152,449,000.00$ \\
\hline & Maintenance of the southern backyard area & $155,809,291.22$ \\
\hline & $\begin{array}{l}\text { Improvements of workspace and changing room for Security } \\
\text { Officer }\end{array}$ & $195,145,000.00$ \\
\hline & Mechanical and Electrical maintenance & $112,670,800.35$ \\
\hline & CCTV maintenance and improvements & $65,227,470.00$ \\
\hline & Storing cabinet repairs & $118,556,000.00$ \\
\hline & Repainting of stairway walls and hallways & $154,407,000.00$ \\
\hline & Wallpaper replacements & $180,931,000.00$ \\
\hline & Roof leakage repairs & $147,704,000.00$ \\
\hline & Sub Total & $1,740,380,561.58$ \\
\hline \multirow[t]{11}{*}{2019} & Roof leakage repairs & $147,704,000.00$ \\
\hline & Interior maintenance of Inspectorate General workspace & $124,976,000.00$ \\
\hline & Toilet maintenance & $94,188,240.00$ \\
\hline & 2nd and 3rd floor interior wall maintenance & $126,896,000.00$ \\
\hline & Interior partition improvements and furniture maintenance & $127,080,000.00$ \\
\hline & $5^{\text {th }}$ floor roof garden maintenance & $109,005,000.00$ \\
\hline & Main Building and basement parking building maintenance & $156,336,000.00$ \\
\hline & Minister workspace area 2nd floor improvements & $183,865,000.00$ \\
\hline & 3rd floor workspace maintenance & $70,930,990.00$ \\
\hline & Sub Total & $1,140,981,230.00$ \\
\hline & TOTAL (Rp/8 years) & $3,748,418,591.58$ \\
\hline
\end{tabular}

From Table 3 and Table 4 above a graph could be made to shows the operation and maintenance cost of the building over a period of 8 years, starting from the beginning of operation until recent year. Figure 13 below shows the trend of increasing operation and maintenance costs over the period of building operation from year 2012 until 2019. O\&M cost from year 2012 shows the lowest cost because the operation of the building starts in August that year, so it was not a full year operation. The total Operation \& Maintenance Cost over 8 years of building operation are Rp57.732.186.283,00. 


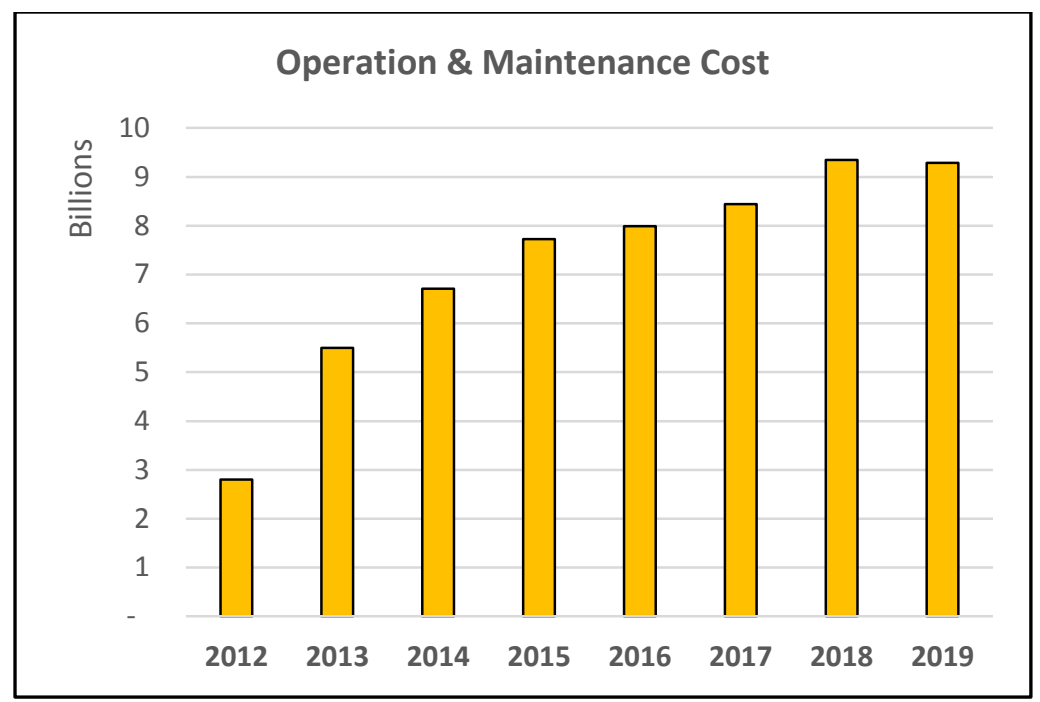

Figure 13. Operation and Maintenance Cost over 8 Years

\section{Energy Cost}

Energy Costs consist of electricity costs and water usage costs. Data collection regarding the energy cost was collected from the monthly electricity bill and water usage bill paid by the Bureau of General Affairs Annual Budget. The total energy cost over 8 years period of building operation are Rp24.235.486.784,00 as shown in Table 5 and Table 6 below.

Table 5. Electricity Cost

\begin{tabular}{|c|c|c|c|c|}
\hline Num. & \multirow{2}{*}{ Year } & $\begin{array}{c}\text { Total Electricity } \\
\text { Consumption } \\
k W h\end{array}$ & $\begin{array}{c}\text { Energi Use } \\
\text { Intensity } \\
k W h / m^{2} / \text { year }\end{array}$ & Annual Cost \\
\hline 1 & 2012 & $1,260,840$ & 118.25 & $1,023,931,559$ \\
\hline 2 & 2013 & $3,276,636$ & 128.04 & $2,990,756,389$ \\
\hline 3 & 2014 & $2,844,586$ & 111.16 & $2,883,603,890$ \\
\hline 4 & 2015 & $3,026,500$ & 118.27 & $3,323,930,737$ \\
\hline 5 & 2016 & $3,143,684$ & 122.85 & $2,731,246,307$ \\
\hline 6 & 2017 & $3,385,022$ & 132.28 & $3,091,599,935$ \\
\hline 7 & 2018 & $3,520,452$ & 137.57 & $3,239,343,425$ \\
\hline 8 & 2019 & $3,794,145$ & 148.27 & $3,484,822,283$ \\
\hline & \multicolumn{3}{|c|}{ TOTAL $($ Rp/8 years $)$} \\
\hline
\end{tabular}


Table 6. Water Usage Cost

\begin{tabular}{|c|c|c|c|c|}
\hline Num. & Year & $\begin{array}{c}\text { Total Water Usage } \\
\mathrm{m}^{3}\end{array}$ & $\begin{array}{c}\text { Water Usage } \\
\text { liter/employee/day }\end{array}$ & $\begin{array}{c}\text { Annual Cost } \\
\text { Rp/year }\end{array}$ \\
\hline 1 & 2012 & 8,190 & 34.87 & $81,429,861$ \\
\hline 2 & 2013 & 20,052 & 35.56 & $196,175,171$ \\
\hline 3 & 2014 & 25,857 & 45.85 & $254,674,440$ \\
\hline 4 & 2015 & 19,486 & 34.55 & $191,494,890$ \\
\hline 5 & 2016 & 18,408 & 32.64 & $180,380,136$ \\
\hline 6 & 2017 & 19,942 & 35.36 & $196,813,616$ \\
\hline 7 & 2018 & 17,249 & 30.59 & $170,278,915$ \\
\hline 8 & 2019 & 19,821 & 35.15 & $195,005,231$ \\
\hline \multicolumn{3}{|c|}{ TOTAL (Rp/8 years) } \\
\hline
\end{tabular}

According to GBCI the Energy Consumption Intensity (IKE) standard for office buildings in Indonesia is $250 \mathrm{kWh} / \mathrm{m}^{2} /$ year. The tariff of electricity for a government office building with power limit above 200KVA (P-2/TM category) provided by National Electricity Company (PT. PLN Persero) is Rp1.115,00 for Non-Peak Load Hour (LWBP) and Rp1672,50 for Peak Load Hour (WBP) as stated in the Minister of Energy and Mineral Resources Regulation (Permen ESDM 28/2016). The average electricity consumption at Central Office Complex of the Ministry of Public Works and Housing observed in the Electricity Bill for a year are 87,5\% at Non-Peak Load Hour and 12,5\% at Peak Load Hour. By comparing the electricity consumption data from Table 5 with the Energy Consumption Intensity (IKE) standard for office buildings, total energy cost saving could be calculated as presented in the table below.

Table 7. Energy Cost Saving Calculation

\begin{tabular}{|c|c|c|c|c|c|c|}
\hline Num. & Year & $\begin{array}{c}\text { Energy } \\
\text { Consumption } \\
\text { Index saving } \\
k W h / \text { m2/year }\end{array}$ & $\begin{array}{c}\text { Total Energy } \\
\text { Consumption }\end{array}$ & $\begin{array}{c}\text { Non Peak } \\
\text { Load Hour } \\
\text { Cost }\end{array}$ & $\begin{array}{c}\text { Peak Load } \\
\text { Hour Cost }\end{array}$ & $\begin{array}{c}\text { Energy Cost } \\
\text { Saving }\end{array}$ \\
\hline 1 & 2012 & 131.75 & $3,371,485$ & $1,370,164,993$ & $294,256,201$ & $1,664,421,194$ \\
\hline 2 & 2013 & 121.96 & $3,120,864$ & $3,043,951,340$ & $653,718,029$ & $3,697,669,370$ \\
\hline 3 & 2014 & 138.84 & $3,552,914$ & $3,465,353,806$ & $744,218,290$ & $4,209,572,096$ \\
\hline 4 & 2015 & 131.73 & $3,371,000$ & $3,287,922,822$ & $706,113,268$ & $3,994,036,089$ \\
\hline 5 & 2016 & 127.15 & $3,253,816$ & $3,173,626,782$ & $681,567,086$ & $3,855,193,869$ \\
\hline 6 & 2017 & 117.72 & $3,012,478$ & $2,938,236,478$ & $631,014,739$ & $3,569,251,216$ \\
\hline 7 & 2018 & 112.43 & $2,877,048$ & $2,806,144,105$ & $602,646,622$ & $3,408,790,727$ \\
\hline 8 & 2019 & 101.73 & $2,603,355$ & $2,539,196,178$ & $545,316,970$ & $3,084,513,148$ \\
\hline & \multicolumn{7}{|c|}{ TOTAL $($ Rp/ $/ 8$ years $)$} \\
\hline
\end{tabular}

Based on Indonesian National Standard (SNI 03-7065-2005) the minimum water usage according to building use is 50 liters/employee/day for an office building. The water tariff being paid to PAM Jaya as Regional Water Provider in Jakarta is $\mathrm{Rp} 9.800,00 / \mathrm{m}^{3}$ based on the Governor Regulation of DKI Jakarta Province (Pergub 91/2017). The total employee occupied the Ministry of Public Works and Housing Main Building are 1545 persons. Using the standard water usage, total employee, water tariff, and water usage data from Table 6 a calculation could be made to determine the water usage cost-saving, as presented in the table below. 
Table 8. Water Usage Cost-Saving calculation

\begin{tabular}{|c|c|c|c|c|}
\hline Num. & \multirow{2}{*}{ Year } & Water Usage saving & $\begin{array}{c}\text { Total Water } \\
\text { Usage saving }\end{array}$ & $\begin{array}{c}\text { Water } \\
\text { Consumption } \\
\text { Cost Saving } \\
\text { Rp/year }\end{array}$ \\
\hline 1 & 2012 & 15.13 & 3552 & $34,812,985$ \\
\hline 2 & 2013 & 14.44 & 8144 & $79,813,650$ \\
\hline 3 & 2014 & 4.15 & 2339 & $22,924,650$ \\
\hline 4 & 2015 & 15.45 & 8710 & $85,360,450$ \\
\hline 5 & 2016 & 17.36 & 9788 & $95,924,850$ \\
\hline 6 & 2017 & 14.64 & 8254 & $80,891,650$ \\
\hline 7 & 2018 & 19.41 & 10947 & $107,278,595$ \\
\hline 8 & 2019 & 14.85 & 8376 & $82,082,197$ \\
\hline & \multicolumn{3}{|c|}{ TOTAL (Rp/8 years) } & $\mathbf{5 8 9 , 0 8 9 , 0 2 8}$ \\
\hline
\end{tabular}

From calculation result in Table 7 and Table 8 the total Energy Cost Saving of Ministry of Public Works and Housing Main Building over 8 years period of building operation is Rp28.072.536.738,00.

\section{Building Expenditure and Building Cost History}

Based on the Initial Cost, Operation \& Maintenance Cost, and Energy Cost that has been compiled above the total building expenditure could be calculated and the result is Rp483.584.506.649,00 as presented in Table 9 below.

Table 9. Building Expenditure 2009 - 2019

\begin{tabular}{|r|l|r|r|}
\hline Num. & \multicolumn{1}{|c|}{ Category } & \multicolumn{1}{c|}{ Cost } & Percentage \\
& & $R p$ & \\
\hline 1 & Initial Cost & $401,616,833,582.00$ & $83.05 \%$ \\
\hline 2 & O\&M Cost & $57,732,186,283$ & $11.94 \%$ \\
\hline 3 & Energy Cost & $24,235,486,784$ & $5.01 \%$ \\
\hline \multicolumn{2}{|c|}{ TOTAL } & $\mathbf{4 8 3 , 5 8 4 , 5 0 6 , 6 4 9}$ & $\mathbf{1 0 0 \%}$ \\
\hline
\end{tabular}

From its inception until its operation until recent years a graph showing the building cost history over the years could be made based on the cost of the contract related activities. At the beginning of its inception in 2009 the early activities related to cost are construction management contract, followed by design and supervision contract and construction contract, all of it categorized as Initial Cost. Operation \& Maintenance Cost and Energy Cost starts from 2012 were initiated after the building was completely built and FHO took place. The result presented as following : 
Table 10. Building Cost History 2009-2019

\begin{tabular}{|c|c|c|c|c|r|}
\hline Num. & Year & Initial Cost & O\&M Cost & Energy Cost & \multicolumn{1}{c|}{ Sum } \\
\cline { 2 - 6 } & & $R p$ & $R p$ & $R p$ \\
\hline 1 & 2009 & $408,430,000.00$ & - & - & $408,430,000.00$ \\
\hline 2 & 2010 & $99,750,000,000.00$ & - & - & $99,750,000,000.00$ \\
\hline 3 & 2011 & $301,458,403,582.00$ & - & $1,105,361,420.70$ & $3,908,066,420.70$ \\
\hline 4 & 2012 & - & $2,802,705,000.00$ & $3,186,931,559.68$ & $8,683,976,635.68$ \\
\hline 5 & 2013 & - & $5,497,045,076.00$ & $3,458,403,582.00$ \\
\hline 6 & 2014 & - & $6,706,812,827.00$ & $3,138,278,329.81$ & $9,845,091,156.81$ \\
\hline 7 & 2015 & - & $7,729,882,600.00$ & $3,515,425,626.63$ & $11,245,308,226.63$ \\
\hline 8 & 2016 & - & $7,989,000,000.00$ & $2,911,626,443.01$ & $10,900,626,443.01$ \\
\hline 9 & 2017 & - & $8,374,056,800.00$ & $3,288,413,550.98$ & $11,662,470,350.98$ \\
\hline 10 & 2018 & - & $9,347,354,272.00$ & $3,409,622,339.29$ & $12,756,976,611.29$ \\
\hline
\end{tabular}

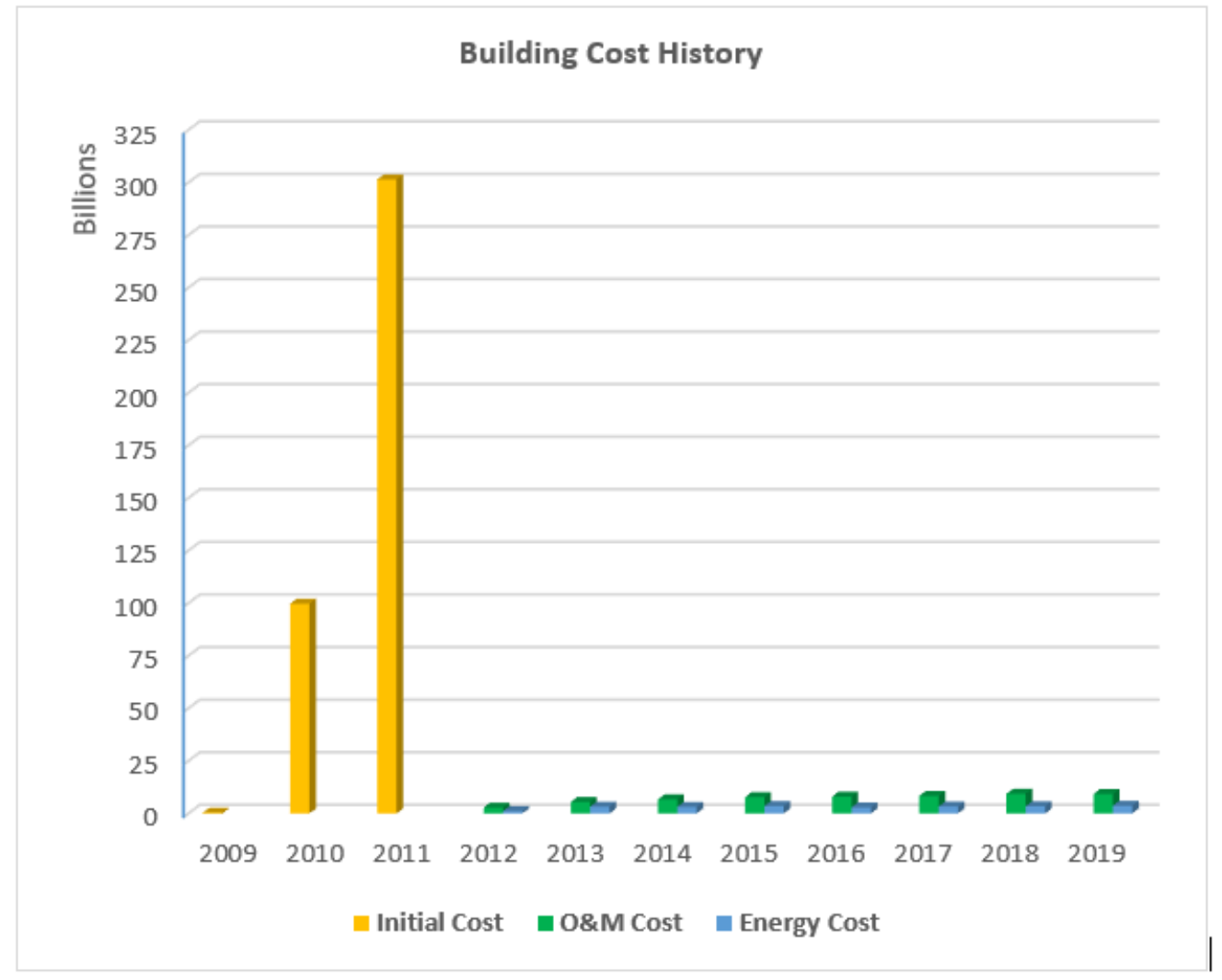

Figure 14. Building Cost History 2009 - 2019

\section{Life Cycle Cost Structure}

Based on the Initial Cost, Operation \& Maintenance Cost, and Energy Cost that has been obtained and compiled above a calculation could be made to determine the Life Cycle Cost Structure of the Ministry of Public Works and Housing Main Building over the period of 8 years of its operation starting from 2012 until 2019. The service life for government buildings was calculated for 50 years as a period the building can continue to fulfill the function and reliability of the building under the established requirements (Permen PU 45/PRT/M/2007). To determine an 8 years life cycle cost, the Initial Cost must be recalculated by considering the service life of the building. The results are as follow: 
Table 11. LCC calculation

\begin{tabular}{|c|l|r|r|r|}
\hline Num. & Category & \multicolumn{1}{|c|}{ Cost } & \multicolumn{1}{c|}{ LCC } & Percentage \\
& & $R p$ & $R p / 8$ years & $\%$ \\
\hline 1 & Initial Cost & $401,616,833,582.00$ & $64,258,693,373.12$ & $43.94 \%$ \\
\hline 2 & O\&M Cost & $57,732,186,283$ & $57,732,186,283$ & $39.48 \%$ \\
\hline 3 & Energy Cost & $24,235,486,784$ & $24,235,486,784$ & $16.57 \%$ \\
\hline \multicolumn{2}{|r|}{ TOTAL } & $\mathbf{1 4 6 , 2 2 6 , 3 6 6 , 4 4 0}$ & $\mathbf{1 0 0 \%}$ \\
\hline
\end{tabular}

From the result presented in Table 10 above a life cycle cost structure model could be presented as shown in Figure 15 below :

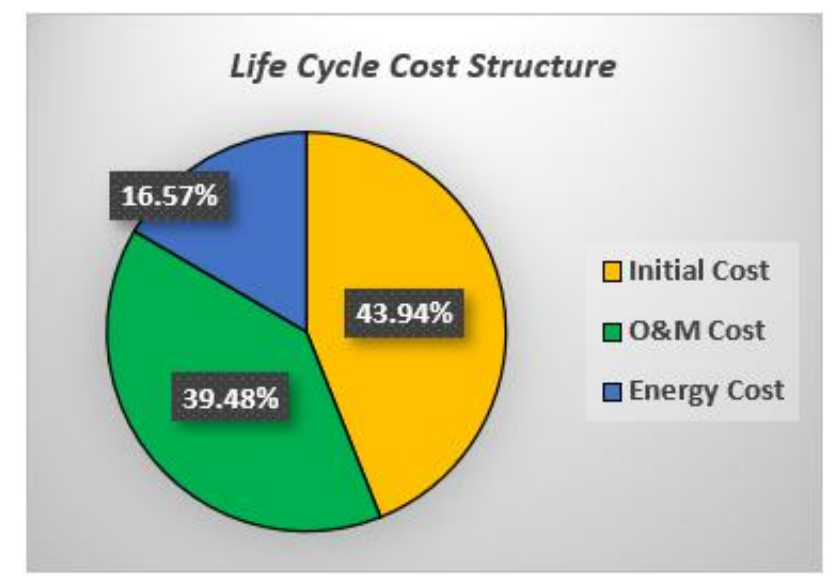

Figure 15. Life Cycle Cost Model of Green Building Over 8 Years

\section{CONCLUSION}

The study regarding Life Cycle Cost has been carried out at a government office green building to determine the Life Cycle Cost Structure over a period of its operational year, with the finding of the cost components. There are three categories of cost for LCC of a green building which are:

1. Initial Cost: $43.94 \%$

2. Operation \& Maintenance Cost: $39.48 \%$

3. Energy Cost: $16.57 \%$

with the total building expenditure is Rp 483.649.711.849,00.

The implementation of green concept in the Ministry of Public Works and Housing Main Building was based on the aspects of energy saving, water usage saving, and environmental friendly. Operation and Maintenance of the building were carried out by the building management operator whose task to monitor and control the performance of the building to achieve a high level of efficiency and energy-saving. Over a period of 8 years of its operation the calculated total Energy Cost saving is Rp 28.072.536.738,00.

\section{REFERENCES}

Barringer, H. Paul (2003). "A Life-Cycle Cost Summary”, International Conference of Maintenance Societies (ICOMS®-2003). http://www.icoms.org.au

Bappenas (2012). Rencana Aksi Nasional Penurunan Gas Rumah Kaca (RAN-GRK).

Bappenas, Jakarta, taken from

http://ranradgrk.bappenas.go.id/rangrk/admincms/downloads/publications/Laporan_Sat u_Tahun_Pelaksanaan_RAN-GRK_RAD-GRK.pdf. 
Chau, C.K, Leung, T. M. \& Ng, W. Y. (2015). "A review on Life Cycle Assessment, Life Cycle Energy Assessment and Life Cycle Carbon Emissions Assessment on buildings". Applied Energy, 143, 395-413.

Erizal, Chadirin, Yudi \& Furi, Iriani Mustika (2019). "Evaluasi Aspek Green Building Pada Gedung Andi Hakim Nasoetion Rektorat IPB". Jurnal Manajemen Aset Infrastruktur \& Fasilitas, Vol.3, No.2, September 2019.

Firsani, Trixie \& Utomo, Christiono (2012). "Analisa Life Cycle Cost pada Green Building Diamond Building Malaysia”. JURNAL TEKNIK ITS, Vol. 1, No. 1, (Sept) ISSN: 2301 9271 hal 34-39.

GBCI (2019). Tentang GBC Indonesia. Green Building Council Indonesia. Accessed from https://www.gbcindonesia.org/ on $2^{\text {nd }}$ October 2019.

ISO 14001:2015. ISO 14001:2015 Environmental Management System. International Organization for Standardization, Geneva.

Kaming, Peter F. (2017). "Implementation of Life Cycle Costing for a University Building". IJoLCAS 1 29-38.

Kelly, John, \& Male, Steven (1993). Value Management in Design and Construction: The Economic Management of Projects. E \& FN, Spon, London.

Pergub DKI 91/17. Peraturan Gubernur Provinsi DKI Jakarta Nomor 91 Tahun 2017 tentang Perubahan Kedua Atas Peraturan Gubernur Nomor 11 Tahun 2007 tentang Penyesuaian Tarif Otomatis (PTO) Air Minum Semester 1, Tahun 2007.

Permen ESDM 28/2016. Peraturan Menteri Energi dan Sumber Daya Mineral Republik Indonesia Nomor 28 Tahun 2016 tentang Tarif Tenaga Listrik yang Disediakan oleh PT. Perusahaan Listrik Negara (Persero).

Permen PU 45/PRT/M/2007. Peraturan Menteri Pekerjaan Umum dan Perumahan Rakyat No 45/PRT/M/2007 tentang Pedoman Teknis Pembangunan Bangunan Gedung Negara.

Permen PU 02/PRT/M/2015. Peraturan Menteri Pekerjaan Umum dan Perumahan Rakyat No 02/PRT/M/2015 tentang Bangunan Gedung Hijau.

PP 27/2014. Peraturan Pemerintah Republik Indonesia Nomor 27 Tahun 2014 tentang Pengelolaan Barang Milik Negara/Daerah.

Pujawan, I. N. (2004). Ekonomi Teknik. Guna Widya. Surabaya.

SNI 03-6572-2001. SNI 03-6572-2001 tentang Tata Cara Perencanaan Sistem Ventilasi Dan Pengkondisian Udara Pada Bangunan Gedung. Badan Standardisasi Nasional.

SNI 03-7065-2005. SNI 03-7065-2005 tentang Tata Cara Perencanaan Plambing. Badan Standardisasi Nasional.

Soemitro, R.A.A \& Suprayitno, H. (2020). "Preliminary Reflection on Basic Problematics of National Public Infrastructure Financing in Indonesia". Journal of Infrastructure \& Facility Asset Management, Vol.2. Issue.1, May 2020

Suprayitno, H. \& Soemitro, R.A.A. (2019). "Reflection on Basic View of Public Infrastructure for Infrastructure Asset Management in Indonesia". Jurnal Manajemen Aset Infrastruktur \& Fasilitas, Volume 3, Sup 1, Juni 2019, Hal.: 15-24.

UNEP (2009). Common carbon metric for measuring energy use and reporting greenhouse gas emissions from building operations. United Nations Environment Programme, Kenya.

US EPA (2016). Green Building. United States Environmental Protection Agency. Accessed from https://archive.epa.gov/greenbuilding/web/html/about.html on $30^{\text {th }}$ September 2019.

Weerasinghe, Achini S., Ramachandra, Thanuja \& Thurairajah, Niraj (2017), "Life Cycle Cost Analysis: Green Vs Conventional Buildings in Sri Lanka". Proceeding of the 33rd Annual ARCOM Conference, eds. Chan, P. W. and Neilson, C. J., Association of Researchers in Construction Management, 309-318. Cambridge, UK. 
Zuo, Jian \& Zhao, Zhen-Yu (2014). "Green building research-current status and future agenda: A review”. Renewable and Sustainable Energy Reviews 30, pp. 271-281. 
(e)ISSN 2656-8896 (p)ISSN 2656-890X

Journal of Infrastructure and Facility Asset Management - Vol. 2, Supplement 1, December 2020 